\title{
HOT STAMP PRESSURE ON ELASTIC HALF-SPACE TAKING INTO ACCOUNT IMPERFECT THERMAL CONTACT THROUGH THIN INTERMEDIATE LAYER
}

\author{
Bohdan Okrepkyi ${ }^{1}$; Tetyana Pyndus ${ }^{2}$; Borys Shelestovs'kyi²
}

\author{
${ }^{1}$ Ternopil National Economic University, Ternopil, Ukraine \\ ${ }^{2}$ Ternopil Ivan Puluj National Tehnical University, Ternopil, Ukraine
}

\begin{abstract}
Summary. The solution of the axially symmetric contact problem of thermal elasticity concerning circular cylindrical isotropic stamp pressure on elastic isotropic half-space, taking into account imperfect thermal contact through thin intermediate layer between the stamp and half-space is developed in this paper. The half-space surface outside the contact area is free from external forces. Tangential stresses in the contact area are equal to zero. Constant temperature is given on the free end face of the cylinder. The lateral surface is thermally insulated and the free half-space surface is maintained at zero temperature. The method of temperature fields determination in the cylinder and half-space, as well as the normal contact stresses under given assumptions is developed. The temperature field, displacement, and stress are represented by unknown coefficients determined from infinite systems of linear algebraic equations. Numerical calculations for defining the temperature and the normal stress temperature component in half-space in the contact area for different values of the intermediate layer thermal conductivity coefficients are carried out.
\end{abstract}

Key words: stamp, half-space, temperature, imperfect thermal contact, thermal conductivity coefficients, contact stresses.

Statement of the problem. Determination of contact deformations and stresses taking into account temperature factors is an important task for the investigation of the machine parts and structural elements strength in places of their interaction while calculating structures on the elastic basis for their rational use and base loading capacity.

Analysis of the available investigations. The influence of temperature factors on the nature of bodies contact interaction is investigated in [1-4]. Particularly, the axisymmetric contact problems of thermal elasticity concerning hot circular stamp pressure on isotropic halfspace and layer are solved in papers [2-3], and for elastic circular cylinder on elastic half-space, taking into account imperfect thermal contact are solved in paper [4] articles [2-3]. However, the problems of thermal conductivity and thermoelasticity taking into account the conditions of imperfect thermal contact of bodies through thin layer intervals have not yet been properly investigated.

The objective of the paper is to develop the solution of the axisymmetric contact elasticity problem concerning pressure of hot circular stamp with flat base on the elastic isotropic half-space with imperfect thermal contact through thin intermediate layer and find formulas for temperature and normal contact stresses determination; to investigate the influence of the intermediate layer thermal conductivity coefficients on the distribution of the normal stresses temperature component.

Statemant of the problem. Let us assume that rigid circular cylindrical stamp of radius $R$ and length $L$ with the flat base is pressed by force $P$ into the isotropic elastic half-space. The half- space surface outside the contact area is free from external forces. 
Tangential stresses on the contact area are $\tau_{r z}=0$. At the free cylinder end face the constant temperature $\mathrm{T}_{0}$ is given. Thermal contact between bodies is carried out through thin intermediate layer $[5,6]$. The free surfaces of the cylinder and the half-space are maintained at zero temperature or thermally insulated. Under given assumptions it is necessary to determine the temperature fields and contact stresses.

Let us introduce the cylindrical coordinate system $r, \theta, z$, which center is located on the half-space surface, and axis $0 z$ is directed along the cylinder axis. All the values indicated by the upper index «1» are referred to the half-space, and those without indices - to the cylinder.

The boundary conditions for temperature, stress and displacement are as follows:

$$
\begin{aligned}
& T=T_{0}, \quad(z=L, \quad 0 \mathrm{~J} \quad r<R) . \\
& \frac{\rrbracket T}{\rrbracket r}=0, \quad(r=R, \quad 0 \mathrm{~J} \quad z<L) \\
& T^{1}=0, \quad(z=0 ; \quad R \mathrm{~J} \quad r<\Gamma) . \\
& \lambda_{0}^{*} \Delta\left(T^{1}+T\right)+2\left(\lambda_{z}^{1} \frac{\partial T^{1}}{\partial z}-\lambda_{z} \frac{\partial T}{\partial z}\right)=0,(z=0 ; \quad 0 \mathrm{~J} \quad r<R) . \\
& \lambda_{0}^{*} \Delta\left(T^{1}-T\right)-6\left(\lambda_{z}^{1} \frac{\partial T^{1}}{\partial z}+\lambda_{z} \frac{\partial T}{\partial z}\right)-12 h_{0}\left(T^{1}-T\right)=0 . \\
& \frac{1}{2} \frac{\partial\left(T^{1}+T\right)}{\partial r}+\frac{\alpha_{0}^{*}}{\lambda_{0}^{*}}\left(\frac{T^{1}+T}{2}-T_{c}\right)=0,(z=0 ; r=R) . \\
& \frac{1}{2} \frac{\partial\left(T^{1}-T\right)}{\partial r}+\frac{\alpha_{0}}{\lambda_{0}^{*}}\left(\frac{T^{1}-T}{2}-T_{c}^{*}\right)=0,(z=0 ; r=R) . \\
& U_{z}^{(1)}=-\varepsilon \quad(z=0 ; 0 \leq r \leq R) \\
& \tau_{z}^{(1)}=0 \quad(z=0 ; R \leq r<\infty) \\
& \tau_{r z}^{(1)}=0 \quad(z=0 ; 0 \leq r<\infty)
\end{aligned}
$$

where $l_{z}, l_{z}^{1}$ are thermal conductivity coefficients; 
$\Delta=\frac{\partial^{2}}{\partial r^{2}}+\frac{1}{r} \frac{\partial}{\partial r}$ is Laplace operator; $T_{c}=\frac{1}{2 d}{ }_{-d}^{d} T_{c}^{0} d g, T_{c}^{*}=\frac{3}{2 d^{2}}{ }_{-d}^{d} g T_{c}^{0} d g, 2 d$ is intermediate layer thickness;

$l_{0}^{*}=2 l_{0} d, h_{0}=\frac{l_{0}}{2 d} ; a_{0}^{*}=2 a_{0} d ; l_{0}, a_{0}-$ are coefficients of intermediate layer thermal conductivity and heat transfer;

$h_{0}$ is contact conductivity;

$T_{c}^{0}$ is external environment temperature;

$\varepsilon-$ is the value of the stamp vertical movement.

Solution of boundary value problems for thermal conductivity and thermal elasticity equations.

It is known [7] that in the axisymmetric case the thermoelastic potential and the temperature field for isotropic body are determined from the equations:

$$
\nabla^{2} \varphi=\alpha_{T} \frac{1+\sigma}{1-\sigma} T, \nabla^{2} T=0
$$

and temperature stresses and displacements are derived by the formulas:

$$
u_{z}^{(T)}=\frac{\partial \varphi}{\partial z}, \sigma_{z}^{(T)}=-2 \mu\left(\frac{1}{r} \frac{\partial \varphi}{\partial r}+\frac{\partial^{2} \varphi}{\partial r^{2}}\right), \tau_{r z}^{(T)}=2 \mu \frac{\partial^{2} \varphi}{\partial r \partial z}
$$

where $\alpha_{T}$ is the coefficient of linear temperature expansion; $\mu, \sigma$ are shear modulus and Poisson ratio.

In order to determine the temperature field in half-space, we introduce Hankel transform of $T^{1}(r, z)$ zero-order function

$$
\overline{T^{1}(\xi, z)}=\int_{0}^{\infty} r T^{1}(r, z) J_{0}(\xi, z) d r
$$

Applying to the second equation (10) the integral Hankel transformation and using its properties, we determine $T^{1}(r, z)$ by arbitrary function $\varphi_{1}(\eta)$ :

$$
T^{1}(\rho, \zeta)=\int_{0}^{\infty} \varphi_{1}(\eta) e^{\eta \zeta} J_{0}(\eta \rho) d \eta
$$

where $J_{0}(\eta \rho)$ is Bessel function of the first kind of valid argument; $\rho=\mathrm{r} / \mathrm{R} ; \zeta=\mathrm{Z} / \mathrm{R} ; \eta=\xi \mathrm{R}$.

Using Fourier method, the general solution to equation (10) is as follows:

$$
\begin{aligned}
T(r, z)=A_{0} z+B_{0} & +D_{0}\left(r^{2}-2 z^{2}\right)+\sum_{\kappa=1}^{\infty} J_{0}\left(\beta_{\kappa} r\right)\left(\mathrm{A}_{\kappa} \operatorname{sh} \beta_{\kappa} z+B_{\kappa} \operatorname{ch} \beta_{\kappa} z\right)+ \\
& +\sum_{\kappa=1}^{\infty} I_{0}\left(\gamma_{k} r\right)\left(C_{\kappa} \sin \gamma_{\kappa} z+D_{\kappa} \cos \gamma_{\kappa} z\right)
\end{aligned}
$$


where $\mathrm{A}_{\kappa}, B_{\kappa}, C_{\kappa}, D_{k},(k=\overline{0, \infty})$ are arbitrary constants; $I_{0}\left(\gamma_{k} r\right)$ is Bessel function of the first kind of imaginary argument;

$\beta_{\kappa}, \gamma_{\kappa}$ are eigenvalues determined from boundary conditions.

The thermoelastic potential $\varphi$ is determined from the first equation (10) in the form:

$$
\varphi(\rho, \zeta)=\frac{1}{2} \frac{1+\sigma}{1-\sigma} \alpha_{T^{1}} \zeta \int_{0}^{\infty} \frac{1}{\eta} \varphi_{1}(\eta) e^{\eta \zeta} J_{0}(\eta \rho) d \eta
$$

The components of temperature stresses and displacements are calculated by formula (12). With formulas for temperature stresses and displacements, it is possible to solve the problem under mechanical boundary conditions. For this purpose it is necessary to add the components of stresses and displacements from the biharmonic potential [1] to the values calculated according to formulas (12).

Thus, in order to determine the displacements and stresses in the isotropic half-space we have the following relations:

$$
\begin{gathered}
U_{z}^{(1)}=-\int_{0}^{\infty} \frac{1}{\eta}\left[\frac{1}{b_{1}^{1} R} \eta \phi_{1}(\eta)+\left(-2+\frac{1}{b_{1}^{1} R} \eta \varsigma\right) \phi_{2}(\eta)\right] e^{\eta \varsigma} J_{0}(\eta \rho) d \eta+ \\
+\frac{1}{2} \frac{1+\sigma^{1}}{1-\sigma^{1}} \alpha_{T^{1}} R \int_{0}^{\infty} \frac{1}{\eta} \varphi_{1}(\eta)(1+\eta \varsigma) J_{0}(\eta \rho) d \eta, \\
\sigma_{z}^{(1)}=\frac{2 b_{3}^{1} \int_{0}^{\infty}}{R}\left[-\frac{\eta}{R} \phi_{1}(\eta)+\left(b_{1}^{1}-\eta \varsigma\right) \phi_{2}(\eta)\right] e^{\eta \varsigma} J_{0}(\eta \rho) d \eta+ \\
+\mu^{1} \frac{1+\sigma^{1}}{1-\sigma^{1}} \alpha_{T^{1}} \varsigma \int_{0}^{\infty} \eta \varphi_{1}(\eta) e^{\eta \varsigma} J_{0}(\eta \rho) d \eta, \\
\tau_{r z}^{(1)}=2 b_{3}^{1} \int_{0}^{\infty}\left[\frac{\eta}{R} \varphi_{1}(\eta)+\left(b_{2}^{1}+\eta \varsigma\right)\right] e^{\eta \varsigma} J_{1}(\eta \rho) d \eta- \\
-\mu^{1} \frac{1+\sigma^{1}}{1-\sigma^{1}} \alpha_{T^{1}}^{\infty} \varphi_{0}^{\infty} \varphi_{1}(\eta)(1+\eta \varsigma) e^{\eta \varsigma} J_{1}(\eta \rho) d_{\eta} .
\end{gathered}
$$

where $b_{1}^{1}=\frac{\mu^{1}}{\lambda^{1}+\mu^{1}}, \quad b_{2}^{1}=\frac{\lambda^{1}}{\lambda^{1}+\mu^{1}}, \quad b_{3}^{1}=\lambda^{1}+\mu^{1} ; \lambda^{1}, \mu^{1}$ are Lame coefficients; $U_{z}^{1}, \sigma_{z}^{1}, \tau_{r z}^{1}$ are components of the displacement vector and tensor stresses in elastic half-space; $\varphi_{i}(i=1,2)$ are arbitrary functions.

The heat conductivity problem solution is given in paper [8].

The temperature field in the contact area of two bodies is found by the formulas:

a) for cylindrical area:

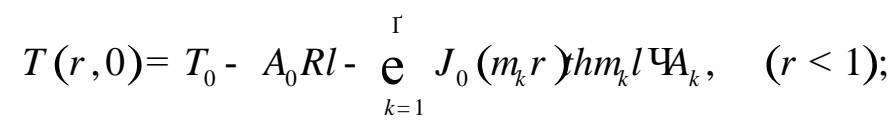


b) for half-space:

$$
T^{1}(r, 0)=a_{0}+\mathrm{e}_{k=1}^{N} a_{k} J_{0}\left(m_{k} r\right), \quad(r<1) ;
$$

where $X_{k}(k=\overline{0, N}), Y_{0}, Y_{1}$ are derived from the system of linear algebraic equations [8].

$$
\begin{gathered}
\sum_{k=0}^{N} A_{n, k}^{(1)} X_{k}+B_{n, 0}{ }^{(1)} Y_{0}+B_{n, 1}{ }^{(1)} Y_{1}=D_{n}^{(1)} \quad(n=\overline{0, N}) \\
\sum_{k=0}^{N} A_{n, k}^{(2)} X_{k}+B_{0,0}{ }^{(2)} Y_{0}=D_{n}^{(2)} \quad(n=\overline{0, N})
\end{gathered}
$$

$A_{n, k}^{(1)}, A_{n, k}^{(2)}, B_{n, 0}^{(1)}, B_{n, 1}^{(1)}, B_{0,0}^{(2)}, B_{0,0}^{(2)}, D_{n}^{(1)}, D_{n}^{(2)}$ are known quantities.

Obeying the boundary condition (9), for stress $\sigma_{z}^{(1)}(\rho, 0)$ and displacement $U_{z}^{(1)}(\rho, 0)$ on the half-space surface we get the formulas:

$$
\begin{gathered}
U_{Z}^{1}(\rho, 0)=\frac{1+b_{1}^{1}}{b_{1}^{1}} R \int_{0}^{\infty} \Phi(\eta) J_{0}(\eta \rho) d \eta+\frac{1}{2} \frac{1+\sigma^{1}}{1-\sigma^{1}} R\left(1+b_{1}^{1}\right) \alpha_{T^{1}} \int_{0}^{\infty} \eta^{-1} \varphi_{1}(\eta) J_{0}(\eta \rho) d \eta, \\
\sigma_{Z}^{1}(\rho)=\frac{2 b_{3}^{1}}{R} \int_{0}^{\infty} \eta \Phi(\eta) J_{0}(\eta \rho) d \eta, \quad R_{\eta} \Phi(\eta)=-\frac{r}{R} \varphi_{1}(\eta)+b_{1}^{1} \varphi_{2}(\eta) .
\end{gathered}
$$

Requiring the fulfillment of the boundary conditions (7), (8) we derive the system of integral equations relatively to functions $\Phi(\eta)$ and $\varphi_{1}(\eta)$ :

$$
\begin{gathered}
\int_{0}^{\infty} \Phi(\eta) J_{0}(\eta \rho) d \eta=-\frac{\varepsilon}{R}-\frac{1}{2} \alpha_{T^{1}} \delta \int_{0}^{\infty} \frac{1}{\eta} \varphi_{1}(\eta) J_{0}(\eta \rho) d \eta, \quad(\rho<1) . \\
\int_{0}^{\infty} \eta \Phi(\eta) J_{0}(\eta \rho) d \eta=0 \quad(\rho>1), \quad \delta=\frac{1+\sigma^{1}}{1-\sigma}\left(1+b_{1}^{1}\right) .
\end{gathered}
$$

If we introduce function $f(t)$ by ratio

$$
\Phi(\eta)=\frac{b_{1}^{1}}{1+b_{1}^{1}} \int_{0}^{1} f(t) \cos \eta t d t
$$

then equation (22) is satisfied identically, and equation (21) is reduced to Abel integral equation.

$$
\int_{o}^{\rho} \frac{f(t) d t}{\sqrt{\rho^{2}-t^{2}}}=g(\rho)
$$

which solution according to [9] is determined by the formula 


$$
f(t)=\frac{2}{\pi} \frac{d}{d t} \int_{o}^{t} \frac{\rho g(\rho)}{\sqrt{t^{2}-\rho^{2}}} d \rho
$$

where

$$
g(\rho)=-\frac{2}{\pi} \frac{\varepsilon}{R}-\frac{\delta}{\pi} \alpha_{T^{1}} \int_{0}^{\infty} \frac{1}{\eta} \varphi_{1}(\eta) J_{0}(\eta \rho) d \eta
$$

Substituting expression (26) into formula (25), taking into account (23), we get the function $f(t)$ :

$$
f(t)=-\frac{2}{\pi} \frac{\varepsilon}{R}-\frac{\delta}{\pi} \alpha_{T^{1}} \int_{0}^{\infty} \frac{1}{\eta} \varphi_{1}(\eta) \cos \eta d \eta
$$

Using the stamp equilibrium condition $P=-2 \pi R^{2} \int_{0}^{1} \rho \sigma_{z}^{(1)}(\rho) d \rho$ and formulas (20), (23), the equation (27) is reduced to the following form:

$$
f(t)=-\frac{P}{2 \pi R^{2} \kappa_{0}}-\frac{\delta}{\pi} \alpha_{T^{1}} \int_{0}^{\infty} \frac{1}{\eta} \varphi_{1}(\eta)\left(\cos \eta t-\frac{\sin \eta}{\eta}\right) d \eta .
$$

Let us represent function $f(t)$ by relation:

$$
f(t)=-\frac{P}{2 \pi R \kappa_{0}} \sum_{k=0}^{N_{1}}(2 k+1) P_{k}\left(1-2 t^{2}\right) y_{k}^{(1)}+\alpha_{T^{1}} T_{0} \sum_{k=0}^{N_{1}}(2 k+1) P_{k}\left(1-2 t^{2}\right) y_{k}^{(2)},
$$

where

$y_{k}^{(1)}\left(k=\overline{0, N_{1}}\right)$ are unknown coefficients;

$P_{k}\left(1-2 t^{2}\right)$ is Legendre function.

Substituting function $f(t)$ from (29) and $\varphi_{1}(\eta)=X_{0} J_{1}(\eta)+\eta^{2} J_{1}(\eta) \sum_{k=1}^{N} \frac{J_{0}\left(\mu_{k}\right)}{\eta^{2}-\mu_{k}^{2}} X_{k}$ into equation (28), taking into account the orthogonality conditions of Legendre functions $P_{k}\left(1-2 t^{2}\right)$ on the interval $(0,1)$, we get the system of linear algebraic equations for finding constants $y_{k}^{(1)}, y_{k}^{(2)}\left(k=\overline{0, N_{1}}\right)$ :

$$
y_{0}^{(1)}=1 ; \quad y_{n}^{(1)}=0, \quad\left(n=\overline{0, N_{1}}\right), \quad y_{n}^{(2)}=\sum_{k=0}^{N} X_{k} i_{n, k}, \quad\left(n=\overline{0, N_{1}}\right),
$$

where 


$$
\begin{gathered}
i_{0,0}=-2 \frac{\delta}{\pi} \int_{0}^{\infty} \frac{1}{\eta} J_{1}(\eta) \tau_{0}(\eta) d \eta \\
i_{0, k}=-2 \frac{\delta}{\pi} J_{0}\left(\mu_{k}\right) \int_{0}^{\infty} \frac{J_{1}(\eta) \tau_{k}(\eta)}{\eta^{2}-\mu_{k^{2}}} d \eta, \\
i_{n, 0}=-\frac{\delta}{\pi}(2 n+1) \int_{0}^{\infty} \frac{1}{\eta} J_{1}(\eta) \tau_{n}(\eta) d \eta,\left(n=\overline{0, N_{1}}\right), \\
i_{n, k}=-\frac{\delta}{\pi}(2 n+1) J_{0}\left(\mu_{k}\right) \int_{0}^{\infty} \frac{\eta J_{1}(\eta) \tau_{n}(\eta)}{\eta^{2}-\mu_{k}^{2}} d \eta, \\
\tau_{n}(\eta)=\frac{1}{4} \eta \gamma_{n}\left(\frac{\eta}{2}\right)\left[\gamma_{n-1}\left(\frac{\eta}{2}\right)-\gamma_{n+1}\left(\frac{\eta}{2}\right)\right]-\frac{(-1)^{n} \sin \eta}{\Gamma(1+\eta) \Gamma(1-\eta) \eta}, \quad\left(n=\frac{1}{\eta}+\frac{1}{2} \sin \eta\right),
\end{gathered}
$$

$\gamma_{n}(x)$ are spherical functions.

In order to determine the contact stresses under the stamp, taking into account formulas (20), (23), (29), the following expressions were obtained:

$$
\begin{gathered}
\sigma_{z}^{(1)}(\rho, 0)=\sigma_{z}^{(P)}(\rho, 0)+\sigma_{z}^{(T)}(\rho, 0), \\
\sigma_{z}^{(P)}(\rho, 0)=-\frac{P}{2 \pi R^{2}} \frac{1}{\sqrt{1-\rho^{2}}}, \\
\sigma_{z}^{\left(T^{1}\right)}=\alpha_{T} T_{0} \frac{\chi_{0}}{\sqrt{1-\rho^{2}}}\left[Y_{0}^{(2)}+\frac{1}{\rho} \sum_{k=1}^{N_{1}}(-1)^{k}(2 k+1) T_{2 k+1}(\rho)\right],(\rho<1),
\end{gathered}
$$

where $T_{2 k+1}(\rho)$ is Chebyshev function; $\sigma_{z}^{(P)}(\rho, 0)$ is force component of stresses; $\sigma_{z}^{\left(T^{1}\right)}(\rho, 0)$ is temperature component of stresses in half-space.

Analysis of the solution. The solution of the temperature problem is to determine the constants $X_{k}(k=\overline{0, N}), Y_{0}, Y_{1}$ from the algebraic equations system due to which the temperature fields at any point of the cylinder and half-space are found.

The numerical example for finding the temperature and temperature component of normal stress in the contact area at $\alpha_{0}^{*}=0, T_{c}^{0}=0, \sigma=0,3$ is considered.

Figures 1 and 2 show The graphs of the dimensionless temperature component of the normal stress $\overline{\sigma_{z}}=\sigma^{T}(\rho, 0) / \alpha_{T_{1}} T_{0}$ in the contact area at different values of thermal conductivity coefficients and contact conductivity value are shown in Figures 1 and 2. 


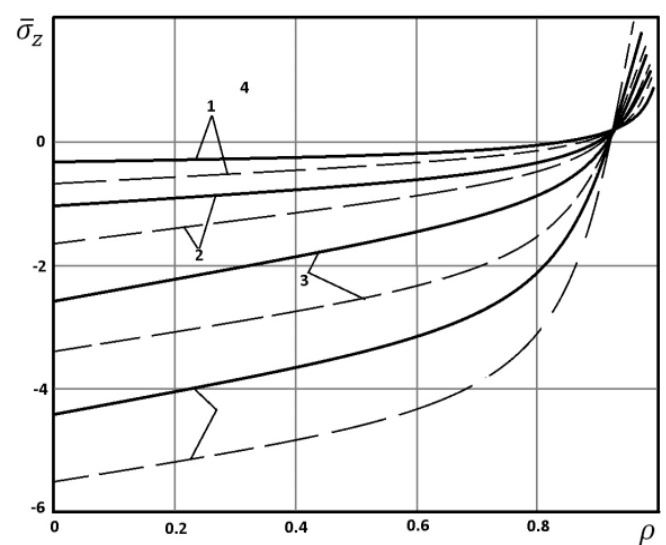

Figure 1. Distribution of temperature component of contact stresses for $\ell_{z}=\ell_{z}^{1}=\infty$ (dotted line) and

$$
\begin{gathered}
\ell_{z}=\ell_{z}^{1}=1 \text { (solid lines): curve } \\
1=h_{0}^{1}=0,1 ; 2-h_{0}^{1}=1 ; 3-h_{0}^{1}=5 ; 4-h_{0}^{1}=\infty .
\end{gathered}
$$

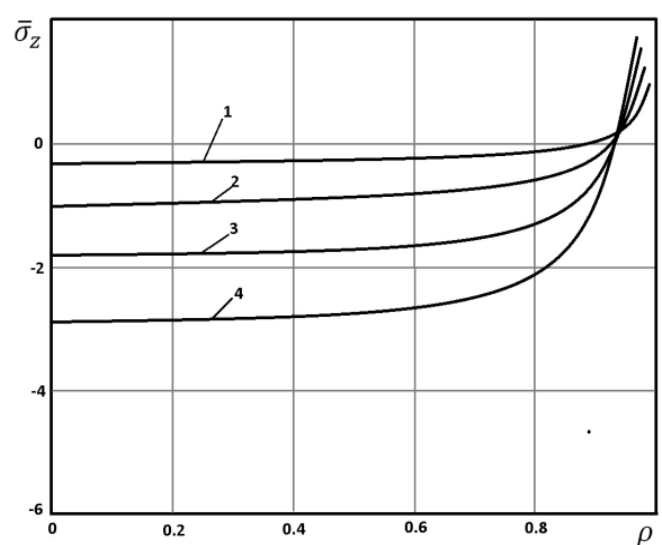

Figure 2. Distribution of the temperature component of contact stresses at $h_{0}^{1}=1, \ell_{z}=\ell_{z}^{1}$ curve $1-\ell_{z}=0,1 ; \quad 2-\ell_{z}=0,5 ; \quad 3-\ell_{z}=1$;

$$
4-\ell_{z}=5 \text {. }
$$

Conclusions. Applying Hankel integral transform and Fourier method, the solution of the temperature problem is reduced to the determination of some constants of the linear algebraic equation through which we find the temperature fields and stresses at any point in the cylinder-half-space body system.

The investigations prove that zero temperature on the lateral surface of intermediate layer results in temperature decrease in the contact area. This is due to the fact that the part of heat comes out of the intermediate layer lateral surface. As the result, the temperature component of the normal stress decreases significantly. The influence of the coefficients of thermal conductivity, heat transfer and contact conductivity on the temperature component of contact stresses is shown in Figures 1, 2. Increase of thermal conductivity coefficients and contact conductivity value results in to an in the contact stresses increase.

\section{References}

1. Grilickij D. V., Kizyma YA. Osesimmetrichnye kontaktnye zadachi teorii uprugosti i termouprugosti. L'vov:Vishcha shkola, 1981. 135 p. [In Russian].

2. Okrepkyi B.S., Shelestovska M. Tysk tsylindrychnoho kruhovoho shtampa na pruzhnyi pivprostir z urakhuvanniam neidealnoho teplovoho kontaktu. Visnyk TNTU. 2006. No. 3. P. 26-33. [In Ukrainian].

3. Okrepkyi B. S. Tysk tsylindrychnoho kruhovoho shtampa na pruzhnyi shar z urakhuvanniam neidealnoho teplovoho kontaktu. Visnyk TNTU. 2011. Vol. 16. No. 2. P. 42-52. [In Ukrainian].

4. Okrepkyi B. S. Osesymetrychna kontaktna zadacha termopruzhnosti pro tysk pruzhnoho tsylindra na pruzhnyi pivprostir z urakhuvanniam neidealnoho teplovoho kontaktu. Visnyk Ternopilskoho derzhavnoho tekhnichnoho universytetu. 2014. No. 2. P. 65-76. [In Ukrainian].

5. Podstrigach Ya. S. Usloviya teplovogo kontakta tverdyih tel. DAN USSR. Seriya A. 1963. No. 7. P. 188-192. [In Russian].

6. Podstrigach Ya.S. Temperaturnoe pole $\mathrm{v}$ sisteme tverdyih tel, soprikasaemyih s pomoschyu tonkogo promezhutochnogo sloya. IFZh. 1963. T. 6. No. 10. P. 129-136. [In Russian].

7. Kovalenko A. D. Osnovy termouprugosti. Kiev: Nauk.dumka, 1970. 304 p. [In Russian].

8. Okrepkyj B. S. Vyznachennja temperaturnogho polja v systemi til cylindr-pivprostir pry neidealjnomu teplovomu kontakti cherez promizhkovyj shar. Visnyk TNTU. 2013. No. 1. P. 253-262. [In Ukrainian].

9. Uitteker E. T. Kurs sovremennogo analiza. M.: Fizmat., 1963. 343 p. [In Russian].

\section{Список використаної літератури}

1. Грилицкий Д. В. Осесиметричные контактные задачи теории упругости и термоупругости. Львов: Выща школа, 1981. 135 с.

2. Окрепкий Б. С. Тиск циліндричного кругового штампа на пружний півпростір з урахуванням неідеального теплового контакту. Вісник ТНТУ. 2006. № 3. С. 26-33.

3. Окрепкий Б. С. Тиск циліндричного штампа на пружний шар з урахуванням неідеального теплового контакту. Вісник ТНТУ. 2011. Т. 16. № 2. С. 42-52.

4. Окрепкий Б. С. Осесиметрична контактна задача термопружності про тиск пружного циліндра на пружний півпростір з урахуванням неідеального теплового контакту. Вісник ТДТУ. 2014. № 2. C. $65-76$. 
Hot stamp pressure on elastic half-space taking into account imperfect thermal contact through thin intermediate layer

5. Подстригач Я. С. Условия теплового контакта твердых тел. ДАН УССР. Серия А. 1963. № 7. С. $188-192$.

6. Подстригач Я. С. Температурное поле в системе твердых тел, соприкасаемых с помощью тонкого промежуточного слоя. ИФЖ. 1963. Т. 6. № 10. С. 129-136.

7. Коваленко А. Д. Основы термоупругости. Киев: Наук. думка, 1970. 304 с.

8. Окрепкий Б. С. Визначення температурного поля в системі тіл циліндр-півпростір при неідеальному тепловому контакті через проміжковий шар. Вісник ТНТУ. 2013. № 1. С. 253-262.

9. Уиттекер Э. Т. Курс современного анализа. М: Физ. мат.: 1963. С. 343.

\title{
УДК 539.3
}

\section{ТИСК ГАРЯЧОГО ШТАМПА НА ПРУЖНИЙ ПІВПРОСТІР 3 УРАХУВАННЯМ НЕІДЕАЛЬНОГО ТЕПЛОВОГО КОНТАКТУ ЧЕРЕЗ ТОНКИЙ ПРОМІЖКОВИЙ ШАР}

\section{Богдан Окрепкий${ }^{1}$ Тетяна Пиндус ${ }^{2}$; Борис Шелестовський ${ }^{2}$}

\author{
${ }^{1}$ Тернопільський національний економічний університет, \\ Тернопіль, Україна \\ ${ }^{2}$ Тернопільський національний технічний університет імені Івана Пулюя, \\ Тернопіль, Украӥна
}

\begin{abstract}
Резюме. Визначення контактних напружень з урахуванням температурних факторів є важливим завданням для дослідження міцності деталей машин і елементів конструкиій у місиях їхньої взаємодї, при розрахунку конструкцї̈ на пружній основі для раціонального використання матеріалу конструкції $i$ несучої здатності основи.

Побудовано розв'язок осесиметричної контактної задачі термопружності про тиск кругового циліндричного ізотропного штампа на пружний ізотропний півпростір з урахуванням неідеального теплового контакту через тонкий проміжків шар між штампом і півпростором. Усі точки основи циліндра під дією зовнішнього навантаження змішуються на однакову величину. Поверхня півпростору зовні площадки контакту вільна від зовнішніх зусиль. Дотичні напруження в зоні контакту дорівнюють
\end{abstract} нулю.

На вільному ториі ичиліндра задана постійна температура. Бічна поверхня теплоізольована, а вільна поверхня півпростору підтримується при нульовій температурі. Тепловий контакт між тілами здійснюється через тонкий проміжний шар. При заданих припущення розвинуто метод визначення температурних полів у ичиліндрі й півпросторі, а також нормальних контактних напружень.

За допомогою методу інтегрального перетворення Ганкеля розв'язано рівняння теплопровідності й термопружності для півпростору, а методом Фур'є - для циліндричної області.

Температурне поле, переміщення ц̆ напруження в ізотропному півпросторі зображено невласними інтегралами з невідомими функціями, які знайдено з граничних умов задачі. Температурне поле, переміщення і напруження подано через невідомі коефіиієнти, які визначаються із нескінченних систем лінійних алгебраїчних рівнянь.

Задоволення граничних умов задачі призводить до системи інтегральних рівнянь, які зв'язують невідомі функиії з коефіцієнтами, щз характеризують температурне поле, $і$ як результат, отримано інтегральне рівняння Фредгольма II-го роду відносно функцій, через які виражені нормальні контактні напруження в півпросторі. Інтегральне рівняння Фредгольма II-го роду розв'язано числовим методом зведенням до системи лінійних алгебраӥчних рівнянь.

Проведено числові розрахунки для знаходження температури й температурної складової нормального напруження в півпросторі у зоні контакту для різних значень коефіцієнтів теплопровідності проміжкового шару.

Числові результати й аналіз розв'язку показують щзо при контактній взаємодії ичліндричного штампа й півпростору коефіцієнти теплопровідності проміжкового шару значно впливають на розподіл температурної складової нормального напруження в зоні контакту.

Ключові слова: штамп, півпростір, температура, неідеальний тепловий контакт, коефіцієнти теплопровідності проміжкового шару, нормальні контактні напруження.

https://doi.org/10.33108/visnyk_tntu2019.04.013

Отримано 24.12.2019 